\title{
Assessing Intellectual Capital from the Perspective of its Rental Income Performance
}

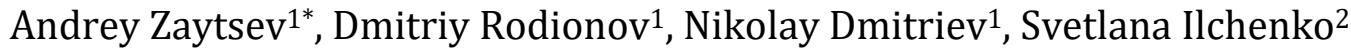 \\ ${ }^{1}$ Peter the Great St. Petersburg Polytechnic University, St. Petersburg, 194021, Russia \\ ${ }^{2}$ Moscow Institute of Economics, Moscow, Russia
}

\begin{abstract}
The transformation processes in economic relations have led to the growing value of intellectual capital, which ensures strategic development of an economic entity. Intangible assets, technological and product innovations are the things that precondition the competitiveness of both the entrepreneurial sector and the national economy as a whole. Thus, it is essential to ensure that the level of intellectual capital of every individual business entity is fairly assessed. Nevertheless, so far there is no versatile method to make such an assessment, which increases the relevance of the search for new ways and their comparison with the existing ones. In this study we suggest developing a methodology for assessing intellectual capital from the perspective of its rental income performance. It is also possible to carry out a comparative analysis of the proposed method and the classical ways that are used to assess the intellectual capital of the enterprise, which include: Tobin's Q approach, market capitalization method and Pulic's method of value added intellectual capital. These methods were tried in an industrial enterprise, operating in the mechanical engineering sector and involved in intensive innovative activities. Based on the data obtained it is possible to conclude that the authors' approach is significant and can be compared with other methods. Assessing the intellectualization level of the enterprise makes it possible to define the strategic perspectives of its long-term development.
\end{abstract}

Keywords: Intangible assets; Intellectual capital; Intellectual capital assessment; Strategic advantages; Sustainable development

\section{Introduction}

This study is aimed at developing methods for assessing the intellectual capital of an economic entity. To do so, it is suggested that the essence of intellectual capital be analyzed as well as the potential possibilities for making this assessment; the classical approaches to assessing intellectual capital be considered; the authors' approach be proposed to carrying out the assessment of intellectual capital from the perspective of its rent income performance; the obtained approach be compared to the classical ones through testing it in an enterprise.

Scientific and technological progress in all sectors of the economy has contributed to the growing significance of intellectual capital for entrepreneurship. Today, innovative development is not possible without intangible elements, stimulating strategic competitiveness. Ubiquitous digitalization poses challenges to modern society where the main role in economic processes is played by people having specific skills, abilities and a

${ }^{*}$ Corresponding author's email: andrey_z7@mail.ru, Tel.: +7-911-248-59-67

doi: 10.14716/ijtech.v11i8.4545 
sufficient level of information. Reproducing intellectual capital is one of the main objectives when the development strategy of an enterprise is being formed (Klein, 2016; Zhilenkova et al., 2019).

When we consider the practice of the most technically advanced countries, we see that the share of material production has been declining and giving way to the intellectual sphere for several decades already, which stimulates the reproduction of highly-qualified personnel. It can be suggested that, in the long run, it is impossible to ensure sustainable development of any economic entity and economy as a whole without intellectualization of the economy (Dal Mas, 2018; Dmitriev et al., 2020; Zaytsev et al., 2020). At the same time, conducting a fair assessment of the intellectual potential of a business entity is problematic. Comparing the outcomes of the company with the trends in its intellectual capital allows us to make conclusions about the efficiency of the company's activities and the significance of intellectualization in achieving entrepreneurial success at this specific firm (Matos et al., 2018).

Thus, the research in the field of intellectualization has not run its course yet, but is gathering steam instead. This study is relevant because there is a lack of a sufficient number of scientific researches on the ways used to assess intellectual capital as economic theory is continually developing.

\section{Literature Review}

In order to undertake this research, we considered works dedicated to the questions of assessment, management and reproduction of intellectual capital as well as to the matters of building an innovation economy. Works dedicated to determining rental income as a result of intellectual labor were studied specifically. The totality of studies allowed us to form these concepts on the significance of intellectual capital and the possibility of conducting this qualitative assessment.

The first fundamental works about the significance of intellectual capital appeared in the second half of the $20^{\text {th }}$ century. In particular, the studies by Schultz (1981) and Machlup (1984) investigated the problems of investing in human resources and educational processes. Among other things, it was proven that growing investments in human capital help support the competitive advantages of business entities and the economic stability of the national economy. Consequently, it is necessary to assess the qualitative aspects of human capital that help to achieve long-term success.

Well-known American economist Drucker (1993) made a large contribution in formulating the theory of intellectual capital. He considered the development of the new society where information products and intangible elements were becoming the main determiners in achieving economic stability and sustainable development. A classical work in the field of intellectual capital is the study by Stewart (1997), which examines the constituent elements of intellectual capital, namely relationship, human and organizational capital, whose synergy effect may maximize the positive effect from doing business.

The studies by Edvinsson and Malone (1997) highlighted that, as early as the late $20^{\text {th }}$ century, the high performance of large international corporations was achieved mainly due to intellectual capital. Material components started to yield their positions, while the intellectual elements of corporate success were outside the control of the owners. While innovations, patents and licenses may be regulated, in many cases the knowledge and talents of individual workers cannot be controlled.

The works of Sveiby (2001) investigated the problems of assessing the intellectual capital of a company. It noted that, if such an assessment is carried out, it meets the interests of many stakeholders, ranging from the economic entity to individual investors. Assessing 
intellectual capital is an important condition for reaching the strategic objectives and must be considered by strategic management when long-term prospects are defined.

Special progress in making the assessment of intellectual capital was noted in the works by Pulic (2012). In particular, Pulic highlighted the efficiency of creating intangible value not only at the entrepreneurial, but also at the national and regional levels. The suggested algorithms of assessment are the most effective. However, qualitative assessment does not always consider the performance of intellectual income in the composition of an economic entity's profit. Pulic also noted that, during the time the economic reality is transforming towards a knowledge economy, intellectual capital should be considered as a resource equal to land, physical assets and financial capital. Consequently, it can be considered from the perspective of rental approaches.

In the context of this research, we analyzed the scientific works of such authors as Roth (2015), Klein (2016), and Matos et al., (2018). We noted that when assessment is being made, the concepts "intellectual capital," "intellectual property" and "intangible assets" cannot be perceived as identical. A complexity in assessing intellectual capital was revealed due to the fact that it can be used more than once in economic turnover.

Some papers on intellectual capital were reviewed for this research. In particular, they included works by Roy (2013), Galeitzke et al. (2015), Dachyar et al. (2015), Jurczak (2016), Dal Mas (2018), Jona-Lasinio et al. (2019), Zhilenkova et al. (2019), Mikalauskiene and Atkociuniene (2019), Durand and Milberg (2020), Qosasi et al. (2019), and Woodhead and Berawi (2020). These researchers highlighted the components of intellectual capital (classical approach: physical, human and structural) whose assessment generates a number of problems, such as the impossibility of referring a specific intangible asset to concrete capital. It is noted that it is practically impossible to define the impact of a concrete type of intellectual capital on the performance indicators of an enterprise, which preconditions the search for integrated approaches.

Scientific and technological progress has led to highlighting intellectual capital as a specific factor of production. However, despite the high significance of intellectual resources at the corporate and territorial level, there are a lot of problems in conducting its fair assessment (Tikhomirov and Komshilova, 2019). The existing studies confirm these constraints, stressing the impossibility of obtaining an objective assessment from such dynamic factors of intellectual capital as employees' experience, skill and specialization (Roth, 2015; Jona-Lasinio et al., 2019). In this context, there is an opportunity to make an assessment from the perspective of performance, for example, rental income performance. Rental issues and their relationship with innovative activities and intellectual capital were studied in the works by Ngo (2016), Zaytsev et al. (2020), Birch (2020), and Maiti et al. (2020).

It is true that the problems related to intellectual capital have been investigated for quite a long time. However, there is still no universal method to carry out a fair assessment. Nevertheless, the significance of intellectual development will be increasingly important year after year while the current elaboration of this area allows us to suggest new methods for assessing the intellectualization of economic entities on different levels. Such research must be done both in the interests of the business sector and the entire national economy (Dal Mas, 2018; Zhilenkova et al., 2019; Durand and Milberg, 2020).

Our work is based on analyzing a vast amount of research in the sphere of intellectualization, which offers a chance to develop new methods of intellectual capital assessment and compare them with the existing methods. The feasibility of the research is confirmed with a possibility of designing guidelines for using the company's intellectual 
capital, revealing its sufficiency and its impact on performance, and considering the average industry-specific indicators of intellectualization.

\section{Research Methodology}

In today's economics there are lots of methods for assessing intellectual capital, for example, determining the amount of costs spent on personnel and/or intellectual property, reevaluating additional or alternative profits, revealing intellectual economic potential, etc. The insufficient number of market criteria and practically impossibility of reporting some intellectual resources in accounting documents make them imperfect, but allow us to obtain specific figures for the analysis. At the same time, the existing methods cannot be called viable, since they do not consider the performance of a business entity (Roy, 2013; Galeitzke et al., 2015).

The classical methods for assessing intellectual capital are: Tobin's cost approach; the market capitalization method; Pulic's value added intellectual capital.

The theoretical essence of the cost approach to intellectual capital ratio was considered by many authors, including Sveiby (2001). This approach is the simplest and can be used to consider the intellectual abilities of the economic entity through its capitalization. Tobin's cost approach is expressed by the formula:

$$
\text { Tobin's Q = MVA/RVA }
$$

where Tobin's $Q$ is the Tobin's q-ratio, MVA is the market value added, RVA is the reuse value added of assets. At Tobin's $Q>1$, the level of intellectual capital is high; At Tobin's $Q$ $<1$, the level of intellectual capital is low.

If the entity's market value and RVA are known, the value of Tobin's $Q$ can be determined (i.e., the relative value of the entity's intellectual value overrun over the material value). Thus, the method does not need a lot of data and can be used to compare companies with a simple structure and low share of diversification. Nevertheless, this assessment method has many disadvantages, which is evidence of its conditionality and inability to take into account a crowd of factors, for example, innovation and strategic risks, or the quality of human capital (Jurczak, 2016; Matos et al., 2018).

The second method of intellectual capital assessment arises from the first one. It is built on the economic entity's market capitalization. Many authors rely on this method, including Edvinsson and Malone (1997), Tikhomirov and Komshilova (2019) and Vetrenko et al. (2017). The market capitalization method is expressed by the formula:

$$
\text { Intellectual C = MVA-BSV }
$$

where Intellectual $C$ is the intellectual capital, MVA is the market value added, and BSV is the book value.

It can be noted that this method, similar to the first method, is conditional; based on its trends, it is virtually impossible to make a quality suggestion about intellectualization of the economic entity. However, it shows the company intellectual value in monetary terms and is the easiest to use, which attracts many researchers who need to obtain data promptly. In turn, the negative results obtained with this approach can be evidence of the negative intellectual position of the business entity (Varadarajan, 2018; Mikalauskiene and Atkociuniene, 2019).

From our point of view, the most comprehensive method is the Value Added Intellectual Coefficient (VAIC) by Pulic. This method can be used to estimate the contribution of tangible or intangible assets in value added. It is noted that the value of the coefficient depends on how efficiently the company uses its intellectual potential. In VAIC- 
based assessment, companies can be compared to each other and the trends in intellectualization levels can be analyzed (Pulic, 2012). The VAIC method is expressed by formula:

$$
\mathrm{VAIC}=\mathrm{SCE}+\mathrm{HCE}+\mathrm{CEE}
$$

where SCE is the structural capital value added, HCE is the human capital value added, and CEE is the physical capital value added.

Some components of this method and their calculation are studied in detail by the scientific community. Based on corporate accounting documents, individual components of intellectual capital can be calculated and their influence on the company performance can be revealed. This method is the most suitable for the comparative analysis with our method.

It is suggested that the methods for intellectual capital assessment be developed on the basis of rental income determination. In order to devise our method, we proposed that mathematical tools be used as well as works dedicated to the matters of identifying intellectual and innovation rental income (Degtereva et al., 2019; Birch, 2020; Maiti et al., 2020). The following formula is suggested for determining the level of enterprise intellectualization:

$$
\mathrm{IC}_{(\text {rent })}=\mathrm{IR}_{\mathrm{ie}} / \mathrm{I}_{\mathrm{ic}}
$$

where $\mathrm{IC}_{\text {(rent) }}$ is the level of enterprise intellectualization, $\mathrm{IR}_{\mathrm{ie}}$ is the value of intellectual rent, and $\mathrm{I}_{\text {ic }}$ is the investment in intellectual development.

Thus, the first step is to define the level of intellectual rent, which can be expressed by the formula:

$$
\mathrm{IR}_{\mathrm{ie}}=\mathrm{I}-\mathrm{C}-\mathrm{N}_{\mathrm{p}}
$$

where I is the enterprise's income, $\mathrm{C}$ is the enterprise's costs, and $\mathrm{N}_{\mathrm{p}}$ is the normal profit per year.

The main complexity in calculating the intellectual rent is in revealing the normal profit. In order to determine the normal profit, it is necessary to analyze the average industry profitability and introduce correction coefficients to minimize the differentiation when comparing different economic entities. The differentiation is caused by the industryspecific and territorial features where enterprises operate. The formula looks like this:

$$
\mathrm{N}_{\mathrm{p}}=\mathrm{A} \times \mathrm{ROA}_{\mathrm{ia}} \times \beta_{1} \times \beta_{2}
$$

where $\mathrm{A}$ is the amount of assets for the end of the year, $\mathrm{ROA}_{\mathrm{ia}}$ is the average coefficient of the return on assets in the industry, $\beta_{1}$ is the correction coefficient related to non-market factors, and $\beta_{2}$ is the correction coefficient related to territorial differentiation.

The next step is to calculate the amount of investments the enterprise allocates for various programs of intellectual development. Such investments can include costs associated with qualitative development of human capital, personnel training and advanced training of labor resources, innovation update, patent activities, etc.

Then, it is possible to measure the efficiency of the used intellectual capital in the context of rental income created in a specific time period, which helps to reveal the weaknesses of the enterprise's strategic development. The negative values of the indicator are evidence of the ineffective investment policy in the field of intellectualization or a sign that there are macroeconomic problems.

\section{Results}

At the next stage, the methods considered above are tested in an industrial enterprise. Comparative analysis of methods for assessing intellectual capital makes it possible to 
judge the intellectualization level of the entity based on the obtained quantitative and relative indicators. For this research, we have chosen an industrial enterprise operating in mechanical engineering and involved in intensive innovative activities.

Table 1 represents the trends in the main indicators to calculate the intellectual capital of the enterprise using the methods of cost approach and market capitalization. Note: MVA, RVA, BSV, and Intellectual Capital C are millions of monetary units; Tobin's Q is the relative indicator.

Table 1 Trends in the indicators considered in the assessment of intellectual capital using classical methods

\begin{tabular}{lcccccccccc}
\hline & 2010 & 2011 & 2012 & 2013 & 2014 & 2015 & 2016 & 2017 & 2018 & 2019 \\
\hline MVA & 1250.44 & 1424.25 & 1553.26 & 1961.96 & 1419.36 & 1590.49 & 1667.86 & 1884.61 & 2155.93 & 2324.14 \\
\hline RVA & 980.55 & 1086.45 & 1100.53 & 1188.17 & 1038.27 & 1138.27 & 1242.42 & 1278.90 & 1306.95 & 1210.28 \\
\hline BSV & 782.37 & 875.47 & 881.40 & 943.23 & 850.23 & 936.63 & 954.95 & 963.28 & 985.78 & 1023.25 \\
\hline Tobin's Q & 1.28 & 1.31 & 1.41 & 1.65 & 1.37 & 1.40 & 1.34 & 1.47 & 1.65 & 1.92 \\
\hline $\begin{array}{l}\text { Intellectual } \\
\text { Capital C }\end{array}$ & 468.07 & 548.78 & 671.85 & 1018.73 & 569.12 & 653.86 & 712.90 & 921.32 & 1170.14 & 1300.89 \\
\hline
\end{tabular}

Figures 1 and 2 graphically illustrate the trends in intellectual capital assessment using classical assessment methods. In the entire period, the indicators of intellectual capital were growing, except for the crisis period of 2014-2015, which was due to macroeconomic instability. A slight reduction in Tobin's Q was observed in 2016, which can be related to problems of strategic development in the enterprise.

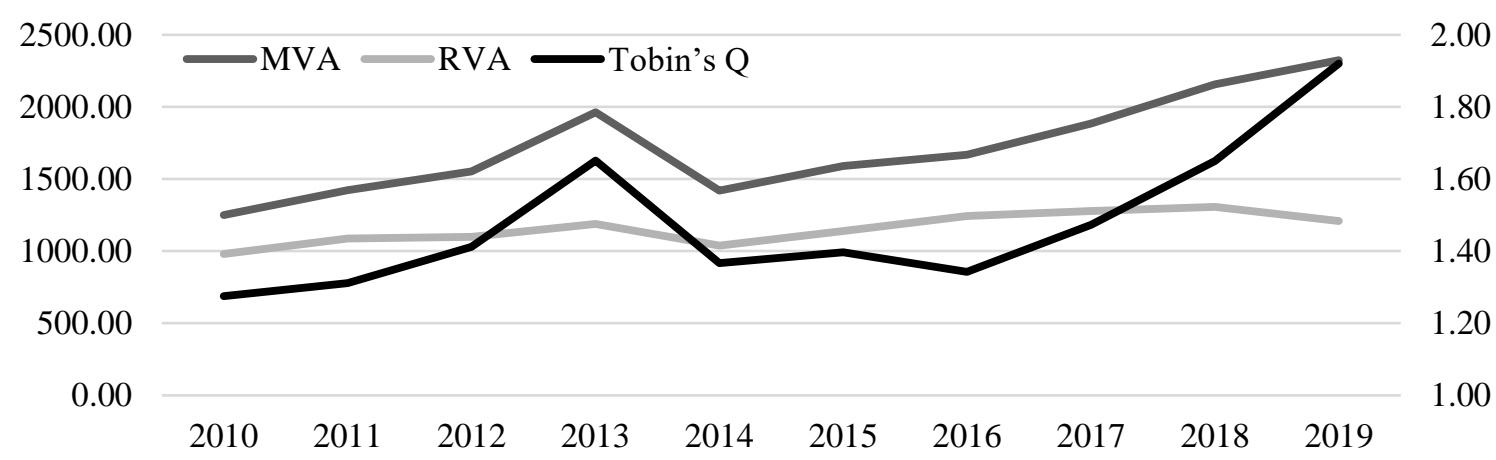

Figure 1 Trends in the indicators considered in the assessment of intellectual capital using the cost approach method

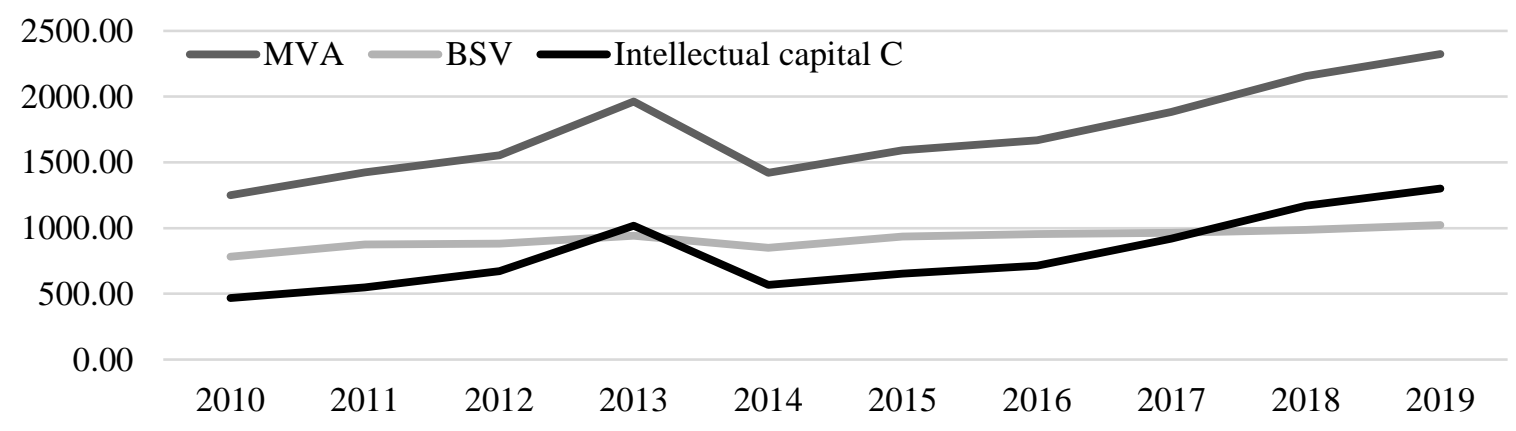

Figure 2 Trends in the indicators considered in the assessment of intellectual capital using the market capitalization method 
The third approach to assessing intellectual capital is the method for defining the VAIC. Table 2 contains the data necessary for calculating the VAIC indicator. The calculation is presented in Table 3. The VAIC indicator was also increasing throughout the entire period that we analyzed, except for the crisis years of 2014-2015, which correspond to the trends in the two previous periods.

Table 2 Data for calculating the VAIC (mil. RUB)

\begin{tabular}{lcccccccccc}
\hline & 2010 & 2011 & 2012 & 2013 & 2014 & 2015 & 2016 & 2017 & 2018 & 2019 \\
\hline Total income & 356.87 & 411.58 & 478.16 & 511.70 & 395.41 & 389.27 & 524.00 & 572.16 & 613.55 & 665.99 \\
\hline $\begin{array}{l}\text { Value of the spent } \\
\text { money }\end{array}$ & 252.29 & 295.98 & 337.15 & 350.90 & 286.97 & 258.41 & 339.93 & 329.16 & 344.42 & 351.42 \\
\hline $\begin{array}{l}\text { Costs of human } \\
\text { capital }\end{array}$ & 37.11 & 39.79 & 42.59 & 46.23 & 38.79 & 38.93 & 48.56 & 59.92 & 63.00 & 60.06 \\
\hline Invested capital & 66.56 & 75.03 & 93.90 & 101.07 & 69.50 & 91.44 & 127.34 & 169.89 & 212.31 & 221.16 \\
\hline
\end{tabular}

Table 3 Calculation of the VAIC

\begin{tabular}{lrrrrrrrrrr}
\hline & 2010 & 2011 & 2012 & 2013 & 2014 & 2015 & 2016 & 2017 & 2018 & 2019 \\
\hline VA & 104.58 & 115.60 & 141.01 & 160.80 & 108.44 & 130.86 & 184.08 & 243.00 & 269.13 & 314.57 \\
\hline HCE & 2.82 & 2.90 & 3.31 & 3.48 & 2.80 & 3.36 & 3.79 & 4.06 & 4.27 & 5.24 \\
\hline SC & 67.47 & 75.80 & 98.42 & 114.57 & 69.65 & 91.93 & 135.52 & 183.07 & 206.12 & 254.51 \\
\hline SCE & 0.65 & 0.66 & 0.70 & 0.71 & 0.64 & 0.70 & 0.74 & 0.75 & 0.77 & 0.81 \\
\hline ICE & 3.46 & 3.56 & 4.01 & 4.19 & 3.44 & 4.06 & 4.53 & 4.81 & 5.04 & 6.05 \\
\hline CEE & 1.57 & 1.54 & 1.50 & 1.59 & 1.56 & 1.43 & 1.45 & 1.43 & 1.27 & 1.42 \\
\hline VAIC & 5.03 & 5.10 & 5.51 & 5.78 & 5.00 & 5.49 & 5.97 & 6.24 & 6.31 & 7.47 \\
\hline
\end{tabular}

Figure 3 graphically illustrates the trends in the VAIC. A considerable growth in the efficiency of the used intellectual capital is observed.

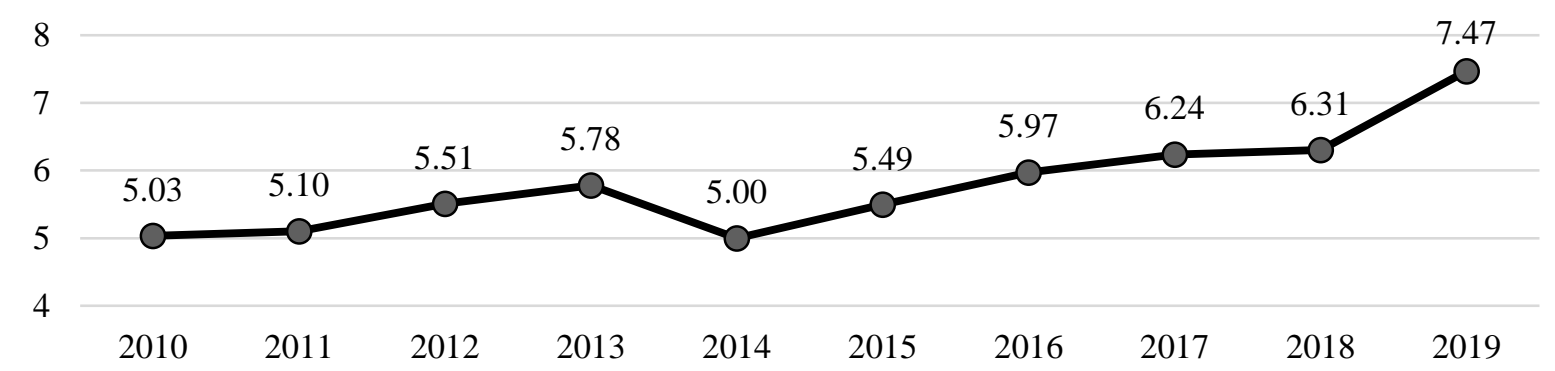

Figure 3 Trends in the VAIC

Table 4 Determining the level of intellectual capital via rental income

\begin{tabular}{lrrrrrrrrrr}
\hline & 2010 & 2011 & 2012 & 2013 & 2014 & 2015 & 2016 & 2017 & 2018 & 2019 \\
\hline $\begin{array}{l}\text { Total } \\
\text { income }\end{array}$ & 356.87 & 411.58 & 478.16 & 511.70 & 395.41 & 389.27 & 524.00 & 572.16 & 613.55 & 665.99 \\
\hline Costs & 306.76 & 352.56 & 417.71 & 436.84 & 358.33 & 327.07 & 442.87 & 466.90 & 488.91 & 514.35 \\
\hline ROA $_{\text {ia }}$ & 4.61 & 4.93 & 4.42 & 5.51 & 5.03 & 5.19 & 5.61 & 5.76 & 5.91 & 6.01 \\
\hline $\mathrm{A}$ & 782.36 & 875.46 & 881.40 & 943.22 & 850.23 & 936.62 & 954.95 & 963.28 & 985.78 & 1023.24 \\
\hline $\mathrm{N}_{\text {pie }}$ & 47.60 & 56.97 & 51.42 & 68.60 & 56.45 & 64.16 & 70.71 & 73.24 & 76.90 & 81.17 \\
\hline $\mathrm{IR}_{\text {ie }}$ & 2.49 & 2.04 & 9.01 & 6.24 & -19.37 & -1.97 & 10.41 & 32.01 & 47.73 & 70.46 \\
\hline Iic & 77.69 & 86.96 & 106.68 & 114.94 & 81.13 & 103.11 & 141.91 & 187.86 & 231.21 & 239.17 \\
\hline $\mathrm{IC}_{\text {(rent) }}$ & 0.03 & 0.02 & 0.08 & 0.05 & -0.23 & -0.01 & 0.07 & 0.17 & 0.20 & 0.29 \\
\hline
\end{tabular}


The next step of comparative analysis is to try our method for assessing intellectual capital through revealing rental income. Table 4 presents the main indicators for calculating intellectual rent and its calculation.

The enterprise was increasing the costs associated with innovative development and improving the quality of intellectual capital throughout the entire period, which resulted in the formation of a considerable level of intellectual rent. This fact is evidence of the achieved production and commercial success due to the use of innovations and human resources. Thus, obtaining our assessment of the intellectualization level of the analyzed enterprise. Figure 4 shows a comparison of our method and the added value of intellectual capital. The trends in the indicators are consistent, as a whole. However, the assessment where rental approaches are used is most sensitive to crisis and reduction in the efficiency of the enterprise activities. It turns out to be an important strength when sensitivity is tested.

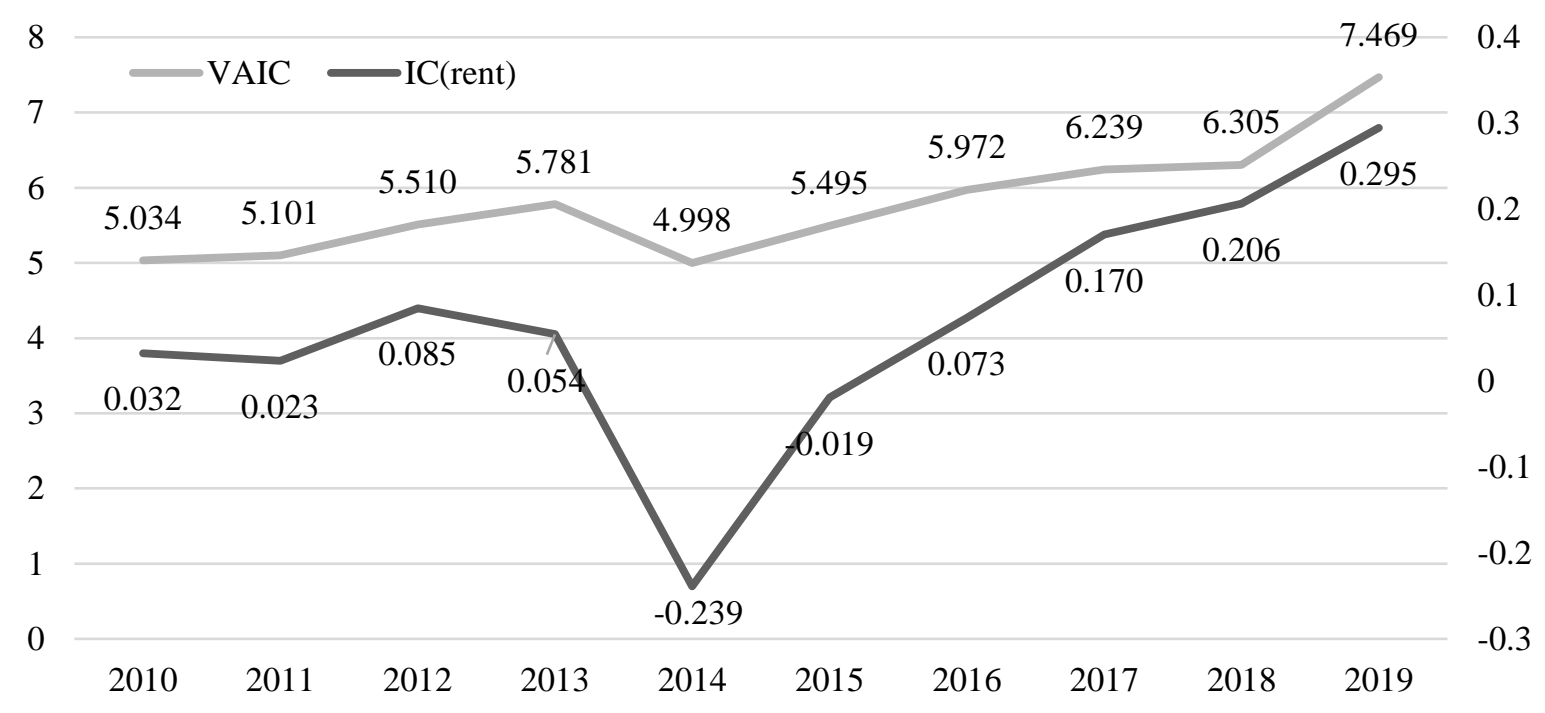

Figure 4 Trends in VAIC and $\mathrm{IC}_{(\mathrm{rent})}$

\section{Discussion}

Our approach in assessing an enterprise proves the viability of the rental approach. It is possible not only to conclude about the availability of intellectual resources at a specific moment in time, but also to learn about the change in trends based on the formation of intellectual rent, and build a comparative characteristic of the results obtained considering other enterprises and their industry-specific features.

It is "favorable" rental income that contributes to creating the competitive advantages of economic entities, while technology and innovation are an essential element launching the creation of rent (Ceccagnoli and Rothaermel, 2016; Ngo, 2016). However, the method can be further improved in the context of its combination with the innovation program of the enterprise and investments in innovative development (Nikolova et al., 2019). It is also possible to form completely new ways of assessing the intellectual potential of the enterprise, which can be used to lay down guidelines aimed at minimizing the negative effects of business activities and to direct the strategy of the enterprise to achieve sustainable development (Ikeuchi, 2017; Mikalauskiene and Atkociuniene, 2019).

\section{Conclusions}

The existing approaches have some constraints, which opens up the potential for further research. In order to develop the methods, the research suggests an assessment of 
intellectual capital using rental approaches. The trial of our method proved its viability and its comparison with the VAIC method showed that there is relative similarity in their trends. Nevertheless, our approach can reflect greater sensitivity towards change in the enterprise performance. Thus, in cases where the rent is negative, the investments made in intellectual capital will not recuperate themselves, which is evidence of the ineffective strategic functioning of the enterprise and a signal that solutions to eliminate negative situations should be urgently explored.

The significance of the work done is confirmed because it is important to reveal excess profits from using intellectual resources. Thus, rental income characterizes the additional intellectual profit of the economic entity. During the time of globalization and innovative development, it is rental income that supports the strategic competitiveness of the enterprise. Assessing intellectual capital in a specific time period by revealing rent is a new, but promising area of research, which opens opportunities for lots of potential research in the future.

\section{Acknowledgements}

This research work was supported by the Academic Excellence Project 5-100 proposed by Peter the Great St. Petersburg Polytechnic University.

\section{References}

Birch, K.A., 2020. Technoscience Rent: Toward a Theory of Rentiership for Technoscientific Capitalism. Science Technology and Human Values, Volume 45(1), pp. 3-33

Ceccagnoli, M., Rothaermel, F.T., 2016. Appropriability Strategies to Capture Value from Innovation. Advances in the Study of Entrepreneurship, Innovation, and Economic Growth, Volume 26, pp. 1-31

Dachyar, M., Yadrifil, Pratama, N.R., 2015. Development of Strategy Model for Organizational Innovation through Information Systems in Higher Education in Indonesia. International Journal of Technology, Volume 6(2), pp. 284-290

Dal Mas, F., 2018. The Relationship between Intellectual Capital and Sustainability: An Analysis of Practitioner's Thought. In: Intellectual Capital Management as a Driver of Sustainability: Perspectives for Organizations and Society, Springer, Cham, Switzerland. pp 11-24

Degtereva, V., Zaytsev, A., Kichigin, O., Dmitriev, N., 2019. Application of the Game-Theoretic Method in the Development of an Investment Behavior Strategy. In: $34^{\text {th }}$ IBIMA Conference, pp. 178-184

Dmitriev, N., Zaytsev, A., Dubanevich, L., 2020. Determining the Strategic Prospects of an Enterprise by Assessing the Dynamics of its Intellectual Rent. Montenegrin Journal of Economics, Volume 16(4), pp. 187-197

Drucker, P., 1993. Post-Capitalist Society. UK: Butterworth-Heinemann

Durand, C., Milberg, W., 2020. Intellectual Monopoly in Global Value Chains. Review of International Political Economy, Volume 27(2), pp. 404-429

Edvinsson, L., Malone, M., 1997. Intellectual Capital: Realizing your Company's True Value by Finding Its Hidden Brainpower. USA: Harper Business

Galeitzke, M., Steinhofel, E., Orth, R., Kohl, H., 2015. Strategic Intellectual Capital Management as a Driver of Organisational Innovation. International Journal of Knowledge and Learning, Volume 10(2), pp. 164-181

Ikeuchi, K., 2017. Measuring Innovation in Firms. In: Competition, Innovation, and Growth in Japan. Springer, Singapore

Jona-Lasinio, C., Manzocchi, S., Meliciani, V., 2019. Knowledge Based Capital and Value Creation in Global Supply Chains. Technological Forecasting and Social Change, Volume 148. p. 119709

Jurczak, J., 2016. Intellectual Capital Risk Management for Knowledge-based Organizations. 
In: Risk Management in Public Administration, Raczkowski, K. (ed.), Springer, Cham, Switzerland, pp. 257-282

Klein, D.A., 2016. The Strategic Management of Intellectual Capital. UK: Taylor \& Francis Group

Machlup, F., 1984. Knowledge: Its Creation, Distribution and Economic Significance, Volume III: The Economics of Information and Human Capital. USA: Princeton

Maiti, M., Krakovich, V., Shams, S., Vukovic, D., 2020. Resource-based Model for Small Innovative Enterprises. Management Decision, Volume 58(8), pp. 1525-1541

Matos, F., Vairinhos, V., Selig, P.M., Edvinsson, L., 2018. Intellectual Capital Management as a Driver of Sustainability: Perspectives for Organizations and Society. Switzerland: Springer

Mikalauskiene, A., Atkociuniene, Z., 2019. Knowledge Management Impact on Sustainable Development. Montenegrin Journal of Economics, Volume 15(4), pp. 149-160

Ngo, C.N., 2016. Developmental Rent Management Analysis: Learning, Upgrading, and Innovation. Journal of Economic Issues, Volume 50(4), pp. 1045-1068

Nikolova, L.V., Velikova, M.D., Abramchikova, N.V., 2019. The Investment Program of Industrial Enterprises under Conditions of Limited Resources. In: 33rd IBIMA Conference, pp. 5433-5445

Pulic, A., 2012. Value Creation Efficiency at National and Regional Levels: Case studyCroatia and the European Union. In: Intellectual Capital for Communities: Nations, Regions, and Cities, Bounfour, A., Edvinsson, L. (eds.), Butterworth-Heinemann, Oxford, UK, pp. 197-213

Qosasi, A., Maulina, E., Purnomo, M., Muftiadi, A., Permana, E., Febrian, F., 2019. The Impact of Information and Communication Technology Capability on the Competitive Advantage of Small Businesses. International Journal of Technology, Volume 10(1), pp. 167-177

Roth, A., 2015. Who Gets What - and Why: The New Economics of Matchmaking and Market Design - From Birth to Death and Along the Way. UK: William Collins

Roy, D., 2013. Intellectual Property Strategy for Competitive Advantage. International Journal of Intellectual Property Management, Volume 6(1-2), pp. 36-61

Schultz, T., 1981. Investing in People: The Economics of Population Quality. USA: University of California Press

Schwab, K., 2017. The Fourth Industrial Revolution. USA: Crown Business

Stewart, T., 1997. Intellectual Capital. The New Wealth of Organizations. USA: Currency Doubleday

Sveiby, K.E., 2001. A Knowledge-based Theory of the Firm to Guide in Strategy Formulation. Journal of Intellectual Capital, Volume 2(4), pp. 344-358

Tikhomirov, A., Komshilova, S., 2019. New Approach to Analyzing the Risk of Intellectual Capital in the Structure of the Market Price of Shares. IOP Conference Series: Materials Science and Engineering, Volume 497, p. 012052

Varadarajan, R., 2018. Innovation, Innovation Strategy, and Strategic Innovation. Innovation and Strategy: Review of Marketing Research, Volume 15, pp. 143-166

Vetrenko, P.P., Chernysheva, E.A., Levitina, I.Y., Voronkova, O.V., Mikheeva, D.G., 2017. Encouraging Employees to Increase the Labor Intellectualization Level as a Factor of Evolution of the Intellectual Capital. European Research Studies Journal, Volume 20(4), pp. $568-577$

Woodhead, R., Berawi, M.A., 2020. Value Creation and the Pursuit of Multi Factor Productivity Improvement. International Journal of Technology, Volume 11(1), pp. $111-122$

Zaytsev, A., Dmitriev, N., Talerchik, S., 2020. Intellectual Rent as a Necessary Element in the Transition to Noonomics. In: 35 ${ }^{\text {th }}$ IBIMA Conference, pp. 13560-13570

Zhilenkova, E., Budanova, M., Bulkhov, N., Rodionov, D., 2019. Reproduction of Intellectual Capital in Innovative-Digital Economy Environment. IOP Conference Series: Materials Science and Engineering, Volume 497(1), p. 012065 